\title{
Lychee Honey Accelerates Antibacterial Efficacy of Penicillin and Amoxiclav Against Gram-Positive Bacteria
}

\author{
Nusrat J Vabna ${ }^{1}$, Nadia Sultana ${ }^{2}$, Mahi Khan², Badol Ghosh ${ }^{3}$, Kashfia Nawrin ${ }^{4}$, Mohammad M \\ Billah $^{4 *}$ \\ ${ }^{1}$ Department of Pharmacy, University of Asia Pacific, Bangladesh \\ ${ }^{2}$ Department of Pharmaceutical Sciences, North South University, Bangladesh \\ ${ }^{3}$ Department of Microbiology, Primeasia University, Bangladesh \\ ${ }^{4}$ Department of Pharmacology Research, Institute for Pharmaceutical Skill Development and Research, Bangladesh
}

*Corresponding author: Mohammad M Billah, Department of Pharmacology Research, Institute for Pharmaceutical Skill Development and Research, Bangladesh.

To Cite This Article: Nusrat J Vabna, Lychee Honey Accelerates Antibacterial Efficacy of Penicillin and Amoxiclav Against Gram-Positive Bacteria. Am J Biomed Sci \& Res. 2019 - 6(3). AJBSR.MS.ID.001034. DOI: 10.34297/AJBSR.2019.06.001034.

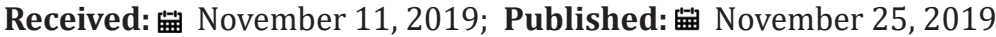

\section{Abstract}

Background: The world has left very few of its last line agents to fight against the common infectious diseases due to the rapidly growing phenomenon of bacterial resistance. Penicillin and amoxicillin-clavulanic acid are among the antibiotics which have already lost their efficacy against resistant bacteria. Thus, the present study was aimed to rejuvenate these two antibiotics supplemented by Lychee Honey as a natural agent.

Methods: The study was performed against four-gram positive bacteria where the standard antibiotics and Lychee honey were applied to assess their individual efficacy. Afterwards, the standards were conjugated with lychee honey to evaluate the boosted potential of the combinations. Zone of inhibition, percentage inhibition, minimum inhibitory concentration and minimum bactericidal concentration were observed in this regard.

Results: Data demonstrated that against all four bacteria, lychee honey alone was able to inhibit the bacterial growth to very little extent (56.5\% against S. epidermidis) whereas the standards showed mild to medium inhibitory potential (64.8\% by Amoxiclav and $60.7 \%$ by Penicillin against S. epidermidis). However, the combination of lychee honey with penicillin and amoxiclav separately demonstrated a synergistic action in all tested methods.

Conclusion: All findings suggested that lychee honey not only possess inhibitory effect but also facilitates other agents' action, thereby, generating a scope for research for identifying new potential antibacterial agents.

Keywords: Lychee honey; Well diffusion; Percentage inhibition; MIC; MBC

Abbreviations: Amoxiclav: Amoxicillin-Clavulanic Acid; MIC: Minimum Inhibitory Concentration; MBC: Minimum Bactericidal Concentration; ATCC: American Type Culture Collection

\section{Introduction}

The phenomenon of antimicrobial resistance in bacterial pathogens is occurring worldwide which is causing serious consequences on the treatment of microbial diseases. The preceding decades have observed a dramatic global increase in human pathogenic bacteria that are resistant to one or multiple antibiotics [1]. The pattern of those multidrug resistant bacteria has threatened the modern medical practice and resulted in increasing morbidity and mortality rates [2]. This antimicrobial resistance

crisis is ascribed to many factors like overuse or misuse of conventional antibiotics, lack of preventive measures in healthcare system, desiderate of new drug development by pharmaceutical industries which would provide the novel treatment options and alternative antibiotic therapies [1,3,4]. A fact, we often overlook is bacteria have inhabited the planet longer than mankind by adapting countless exposure to inhospitable environments. So, it should not be a matter of wonder that they have manifested strong DNA modifying strategies for adaptation and evaluation [5]. 
Penicillin, the first discovered antibiotic has lost its activity against almost all kind of bacteria. Amoxiclav, a potent combination of penicillin and clavulanic acid is also losing its efficacy against many organisms [6]. Thus, finding strategies against resistance development and scheming treatments of drug resistant organisms has become a deep concern for research community and public health [7]. However, development of new antimicrobial therapy by modification of bacteria at genetic level or synthesis of a new drug molecule is a lengthy process which requires a lot of time and investment. A faster alternative can be established by searching the antimicrobial potential in naturally existing sources which can be supplemented with the conventional antibiotics to increase its efficacy or to design a new antibiotic. Natural substances which possess antimicrobial property could be honey, parts of different plants (e.g.: turmeric, neem etc.), essential oil (e.g.: basil, thyme etc.), enzyme derived from animal sources (e.g.: lysozyme, lactoferrin etc.) and so on [8].

Honey, among them, can be a prominent source which is proved to have broad spectrum of antimicrobial activity according to many in-vitro clinical studies. It can be attributed to the high sugar concentration, low $\mathrm{pH}$, osmotic effect, and presence of bacteriostatic and bactericidal factors (e.g.: antioxidants, flavonoids, polyphenols, hydrogen peroxide, lysozymes, methylglyoxal, phenolic acids, bee peptides) $[9,10]$. Honey derived from Lychee (Litchi Chinensis) flower is commonly found and considered to be abundant source of vitamins and minerals which boosts immune system [11]. It has efficacy over hepatotoxicity and cadmium- and lead-induced cytotoxicity, due to the presence of proanthocyanidine $[12,13]$. According to many pharmacological studies, this monofloral honey possess antibacterial activity, antityrosinase, antioxidant property with high MIC (Minimum Inhibitory Concentration) and MBC (Minimum Bactericidal Concentration) value against many organisms [14]. These properties could provide a synergistic effect with antibiotics or increase efficacy of weak antibiotics. Thus, the aim of present study was to boost the activity of Penicillin and Amoxiclav against resistant bacteria by conjugation of Lychee honey.

\section{Methods}

\section{Collection and Preparation of the Sample}

Lychee honey $(1 \mathrm{~kg})$ was collected from a lychee garden situated in Dinajpur district $\left(25.63^{\circ} \mathrm{N} 88.65^{\circ} \mathrm{E}\right)$ of Bangladesh. Honey was directly purchased from a beekeeper after breaking a cultivated hive in the early June 2019. This raw honey was centrifugally extracted which was then allowed to pass through a sieve $(0.5 \mathrm{~mm}$ mesh) to remove non soluble materials (egg, pollen, wax) and other coarse particles. It was stored in a hermetically closed glass container at room temperature $\left(25^{\circ} \mathrm{C}\right)$.

\section{Collection of Bacterial Strains}

Four gram-positive bacterial strains- Bacillus subtilis, Staphylococcus aureus, Staphylococcus epidermidis and
Micrococcus luteus, isolated from feces, cough, nasal mucosa and urine culture respectively. The strains were collected from Center for Medical Biotechnology, Institute of Public Health, Bangladesh. The standard strain of Bacillus subtilis (ATCC 6633), Staphylococcus aureus (ATCC 6538), Staphylococcus epidermidis (ATCC 12228) and Micrococcus luteus (ATCC 9341) were obtained and used as references.

\section{Preparation of Inoculums}

Mueller-Hilton Agar (MHA) plates and Nutrient Broth (NB) tubes were used to sub-culture the collected strain, overnight at $37 \pm 1^{\circ} \mathrm{C}$. In $5 \mathrm{ml}$ of sterile saline water, bacteria could grow. To attain the viable cell count of $107 \mathrm{CFU} / \mathrm{ml}$, the solution was diluted, and absorbance was taken at $580 \mathrm{~nm}$ by using a spectrophotometer [15].

\section{Antimicrobial Susceptibility Test}

Antibiotic susceptibility test was determined by well diffusion method. Each bacterial strain was streaked over the freshly prepared MHA plate $(90 \mathrm{~mm})$ by using a sterile cotton swab. Five equal zones were plotted and $6 \mathrm{~mm}$ well was cut in each zone using a sterile corn borer. $20 \mu \mathrm{l}$ of test agents were poured into wells respectively. Sterile distilled water was used as negative control and a $10 \mu \mathrm{l}$ of $10 \mu \mathrm{g} / 10 \mu \mathrm{l}$ phenoxymethylpenicillin (Sanofi Aventis (BD) Ltd.) and Amoxicillin/Clavulanic Acid (Sanofi Aventis (BD) Ltd.) were used as positive controls. Then the plates were incubated at $37 \pm 1^{\circ} \mathrm{C}$ for $24 \mathrm{~h}$ and zone of inhibition was measured. [16].

\section{Minimum Inhibitory Concentration}

Micro dilution technique is used to measure the Minimum Inhibitory Concentration (MIC) according to Patton et al. with some minor modifications [17]. Two-fold serial dilution was made by using a microplate (96 well) where sterile distilled water was used to produce $50 \%, 25 \%, 12.5 \%, 6.25 \%, 3.12 \%$ and $1.56 \%(\mathrm{v} / \mathrm{v})$ concentrations from the stock honey (100\%). For comparison, phenoxymethylpenicillin and amoxicillin/clavulanic acid were added separately in combination with those concentrations in respective wells. So, each well constituted $200 \mu$ l of Nutrient Broth, $10 \mu \mathrm{l}$ of bacterial suspension, $20 \mu \mathrm{l}$ of honey samples and/or $10 \mu \mathrm{l}$ of standard antibiotics. No antibiotic or testing agent was added in the negative control. A reading of the absorbance of the microwells were taken through Biobase-EL10A ELISA Reader (China) to consider the initial value $\left(T_{0}\right)$. Then the plates were incubated at $37 \pm 1^{\circ} \mathrm{C}$ for $24 \mathrm{~h}$. and again absorbance was taken $\left(T_{24}\right)$. From the difference, percentage inhibition was calculated using the below formula [18]:

$$
\text { Percentage inhibition }=1-(\text { OD test } / O D \text { control }) \times 100
$$

The least concentration of well that showed no visual turbidity was taken as the minimum inhibitory concentration (MIC).

\section{Minimum Bactericidal Concentration}

Minimum Bactericidal Concentration (MBC) was determined by withdrawing $20 \mu \mathrm{l}$ of suspension from the well which showed 
invisible growth with lowest concentration and transferred into MHA plates, having no agent or antibiotic. To observe bacterial growth, plates were incubated for $24 \mathrm{~h}$ at $37 \pm 1^{\circ} \mathrm{C}$. The concentration of honey or its combination at which the plates did not show any bacterial growth was considered as MBC [19].

\section{Statistical Analysis}

All experiments were done in triplet and all data was expressed as mean \pm standard deviation (SD). One-way analysis of variance (ANOVA) was used to determine the significance of differences among honey activities as measured by zone of inhibition. $P<0.05$ was considered statistically significant.

\section{Results}

Figure 1 shows that penicillin and amoxicillin-clavulanic acid exhibit mild antibacterial effect against the tested bacteria. Honey alone at the applied doses could not produce significant efficacy against any of the bacteria. However, when used in combination with the standard drugs, LCH demonstrated greater potency developing zone of inhibitions (Figure 1).

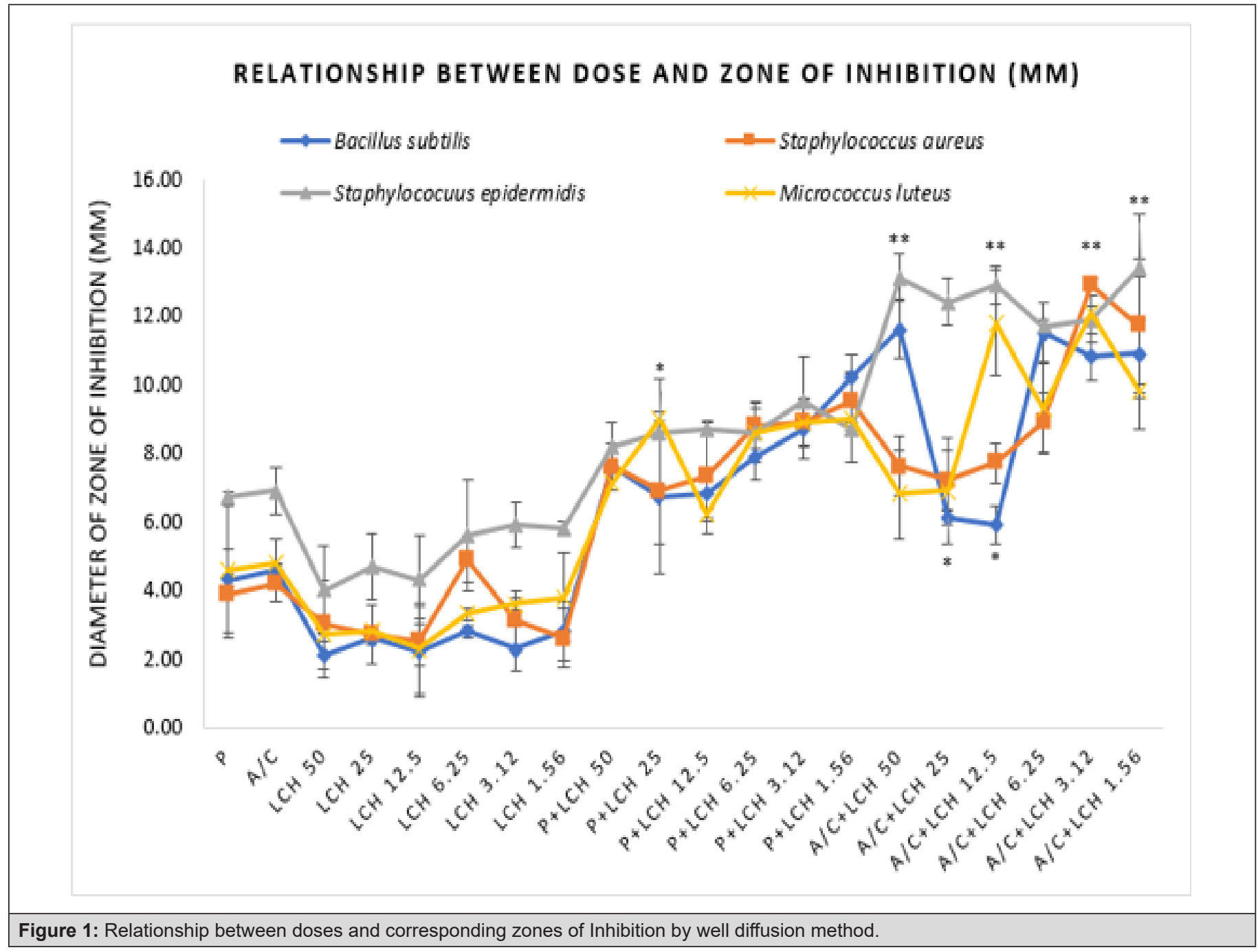

Note: $\mathrm{P}=$ Penicillin, $\mathrm{A} / \mathrm{C}=$ Amoxicillin-Clavulanic Acid, LCH=Lychee (Litchi Chinensis) Honey, P+LCH=Combination of Penicillin and Lychee Honey, $\mathrm{A} / \mathrm{C}+\mathrm{LCH}=$ Combination of Amoxicillin-Clavulanic Acid and Lychee Honey. Data represents diameter (mm) of zone of inhibition expressed as mean \pm standard deviation, $(\mathrm{n}=3) ;{ }^{*} \mathrm{p}<0.05,{ }^{* *} \mathrm{p}<0.01,{ }^{* * *} \mathrm{p}<0.001$; Dunnett $\mathrm{t}$-test (two sided) treated one group as control (no antibacterial agent) and compared all other groups against it.

From the observations of microplate culture, percentage inhibitions against each bacterium have been deduced. Figure $2 \mathrm{a}$ demonstrates that amoxiclav alone could inhibit $42.4 \%$ of $B$. subtilis growth whereas in conjugation with honey it inhibited $97.4 \%$ of the growth. Alongside, with penicillin it showed bacteriostatic effect up to $90.9 \%$ whereas penicillin itself could not resist the growth beyond $35 \%$.
The same trends have been observed in all other tested organism where amoxiclav and penicillin inhibited $99.8 \%$ and $89.5 \%$ S. aureus growth (Figure $2 \mathrm{~b}$ ), $99.1 \%$ and $90.1 \%$ S. epidermidis growth (Figure 2c), $80 \%$ and $91.6 \% \mathrm{M}$. luteus growth respectively (Figure $2 \mathrm{~d}$ ). The trend analysis showed that lychee honey at low doses exhibited greater efficacy in a gradient manner (Figure 2 (a-d)). 


\begin{tabular}{|c|c|c|c|}
\hline Test Bacteria & Sample & MIC & MBC \\
\hline \multirow{5}{*}{ Bacillus subtilis } & $P$ & $\mathrm{~N} / \mathrm{A}$ & $\mathrm{N} / \mathrm{A}$ \\
\hline & $\mathrm{A} / \mathrm{C}$ & $\mathrm{N} / \mathrm{A}$ & $\mathrm{N} / \mathrm{A}$ \\
\hline & $\mathrm{LCH}$ & $\mathrm{N} / \mathrm{A}$ & $\mathrm{N} / \mathrm{A}$ \\
\hline & $\mathrm{P}+\mathrm{LCH}$ & P $1 \mu \mathrm{g} / \mu \mathrm{l}+\mathrm{LCH} 1.56 \%$ & P $1 \mu \mathrm{g} / \mu \mathrm{l}+\mathrm{LCH} 1.56 \%$ \\
\hline & $\mathrm{A} / \mathrm{C}+\mathrm{LCH}$ & $\mathrm{A} / \mathrm{C} 1 \mu \mathrm{g} / \mu \mathrm{l}+\mathrm{LCH} 6.25 \%$ & $\mathrm{~A} / \mathrm{C} 1 \mu \mathrm{g} / \mu \mathrm{l}+\mathrm{LCH} 50 \%$ \\
\hline \multirow{5}{*}{ Staphylococcus aureus } & $P$ & $\mathrm{~N} / \mathrm{A}$ & $\mathrm{N} / \mathrm{A}$ \\
\hline & $\mathrm{A} / \mathrm{C}$ & $\mathrm{N} / \mathrm{A}$ & $\mathrm{N} / \mathrm{A}$ \\
\hline & $\mathrm{LCH}$ & $\mathrm{N} / \mathrm{A}$ & $\mathrm{N} / \mathrm{A}$ \\
\hline & $\mathrm{P}+\mathrm{LCH}$ & $\mathrm{P} 1 \mu \mathrm{g} / \mu \mathrm{l}+\mathrm{LCH} 1.56 \%$ & N/A \\
\hline & $\mathrm{A} / \mathrm{C}+\mathrm{LCH}$ & $\mathrm{A} / \mathrm{C} 1 \mu \mathrm{g} / \mu \mathrm{l}+\mathrm{LCH} 1.56 \%$ & $\mathrm{~A} / \mathrm{C} 1 \mu \mathrm{g} / \mu \mathrm{l}+\mathrm{LCH} 3.12 \%$ \\
\hline \multirow{5}{*}{ Staphylococcus epidermidis } & $P$ & $\mathrm{~N} / \mathrm{A}$ & $\mathrm{N} / \mathrm{A}$ \\
\hline & $\mathrm{A} / \mathrm{C}$ & $\mathrm{N} / \mathrm{A}$ & N/A \\
\hline & $\mathrm{LCH}$ & $\mathrm{N} / \mathrm{A}$ & N/A \\
\hline & $\mathrm{P}+\mathrm{LCH}$ & $\mathrm{N} / \mathrm{A}$ & N/A \\
\hline & $\mathrm{A} / \mathrm{C}+\mathrm{LCH}$ & $\mathrm{A} / \mathrm{C} 1 \mu \mathrm{g} / \mu \mathrm{l}+\mathrm{LCH} 1.56 \%$ & $\mathrm{~A} / \mathrm{C} 1 \mu \mathrm{g} / \mu \mathrm{l}+\mathrm{LCH} 50 \%$ \\
\hline \multirow{5}{*}{ Micrococcus luteus } & $\mathrm{P}$ & N/A & $\mathrm{N} / \mathrm{A}$ \\
\hline & $\mathrm{A} / \mathrm{C}$ & $\mathrm{N} / \mathrm{A}$ & $\mathrm{N} / \mathrm{A}$ \\
\hline & $\mathrm{LCH}$ & $\mathrm{N} / \mathrm{A}$ & $\mathrm{N} / \mathrm{A}$ \\
\hline & $\mathrm{P}+\mathrm{LCH}$ & P $1 \mu \mathrm{g} / \mu \mathrm{l}+\mathrm{LCH} 1.56 \%$ & P $1 \mu \mathrm{g} / \mu \mathrm{l}+\mathrm{LCH} 25 \%$ \\
\hline & $\mathrm{A} / \mathrm{C}+\mathrm{LCH}$ & $\mathrm{A} / \mathrm{C} 1 \mu \mathrm{g} / \mu \mathrm{l}+\mathrm{LCH} 3.12 \%$ & $\mathrm{~A} / \mathrm{C} 1 \mu \mathrm{g} / \mu \mathrm{l}+\mathrm{LCH} 12.5 \%$ \\
\hline
\end{tabular}

Note: Data represents the minimum concentrations at which the applied test samples showed inhibitory and bactericidal effect against the tested bacteria. N/A: No Effect; P: Penicillin; A/C: Amoxicillin-Clavulanic Acid; LCH: Lychee (Litchi Chinensis) Honey; P+LCH: Combination of Penicillin and Lychee Honey; A/C+LCH:Combination of Amoxicillin-Clavulanic Acid and Lychee Honey.

\section{\% Inhibition of B. subtilis Growth by LCH}

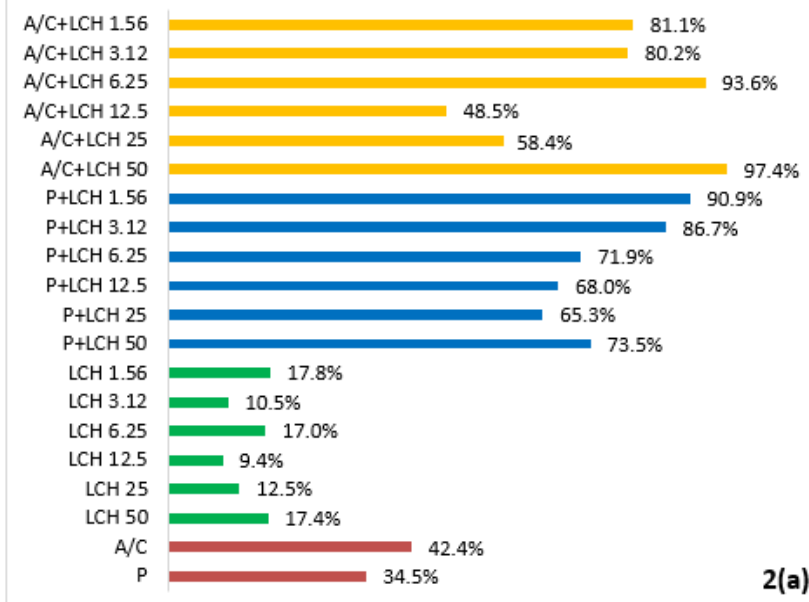

$\%$ Inhibition of $S$. aureus Growth by LCH

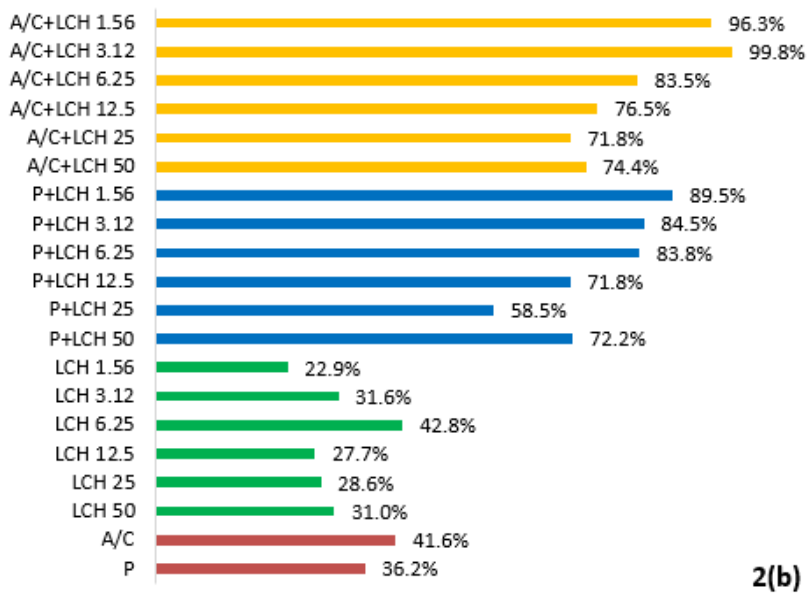

Figure 2 (a-b): \% Inhibition of bacterial growth by lychee honey.

Note: "P=Penicillin, A/C=Amoxicillin-Clavulanic Acid, LCH=Lychee (Litchi Chinensis) Honey, $\mathrm{P}+\mathrm{LCH}=$ Combination of Penicillin and Lychee Honey, $\mathrm{A} / \mathrm{C}+\mathrm{LCH}=$ Combination of Amoxicillin-Clavulanic Acid and Lychee Honey. Data represents inhibition of bacterial growth observed in micro-wells expressed as percentage (\%), treated one group as control (no antibacterial agent applied) and compared all other groups against it.

The same trends have been observed in all other tested organism where amoxiclav and penicillin inhibited $99.8 \%$ and $89.5 \% \mathrm{~S}$. aureus growth (Figure $2 \mathrm{~b}$ ), $99.1 \%$ and $90.1 \% \mathrm{~S}$. epidermidis growth (Figure $2 \mathrm{c}$ ), $80 \%$ and $91.6 \% \mathrm{M}$. luteus growth respectively (Figure $2 \mathrm{~d}$ ). The trend analysis showed that lychee honey at low doses exhibited greater efficacy in a gradient manner". 

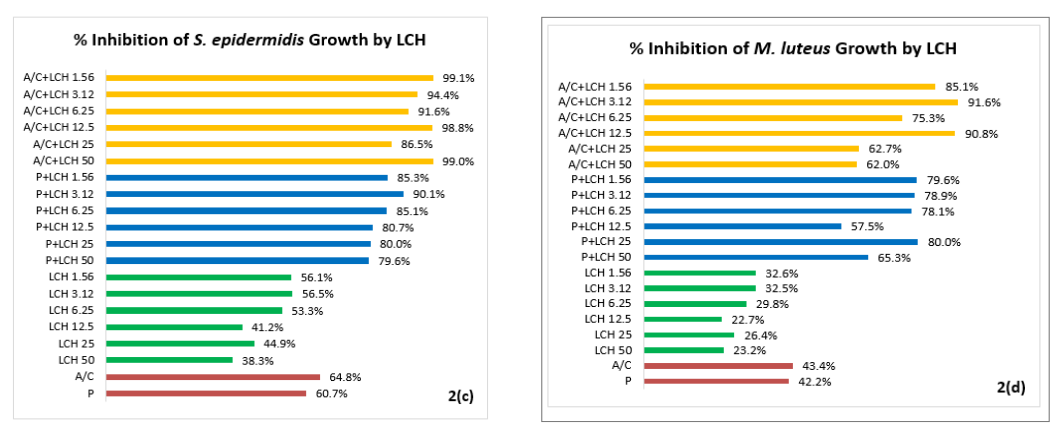

Figure 2 (c-d): \% Inhibition of bacterial growth by lychee honey.

Note: $\mathrm{P}=$ Penicillin, $\mathrm{A} / \mathrm{C}=$ Amoxicillin-Clavulanic Acid, $\mathrm{LCH}=\mathrm{Lychee}$ (Litchi Chinensis) Honey, $\mathrm{P}+\mathrm{LCH}=\mathrm{Combination}$ of Penicillin and Lychee Honey, $\mathrm{A} / \mathrm{C}+\mathrm{LCH}=$ Combination of Amoxicillin-Clavulanic Acid and Lychee Honey. Data represents inhibition of bacterial growth observed in micro-wells expressed as percentage (\%), treated one group as control (no antibacterial agent applied) and compared all other groups against it.

Demonstrated that any of the applied doses for the honey alone was not able to produce bacteriostatic or bactericidal effect. The same was observed for penicillin and amoxiclav when tested individually. However, the combinations with honey showed the potency. Penicillin with the lowest applied dose of lychee honey $(1.56 \%)$ was able to produce both bacteriostatic and bactericidal effect against $B$. subtilis and bacteriostatic effect against $S$. aureus and M. luteus. But it could not produce any effect against S. epidermidis. On the other hand, amoxiclav at different doses exhibited its inhibitory as well as killing potential against all tested organisms.

\section{Discussion}

The nature and quality of a honey can be ascertained from its physicochemical properties. Studies confirmed that lychee honey has low moisture content which indicates the lesser possibilities of bacteria to cause degradation of this honey by the process of fermentation [20]. More than $82 \%$ of the total soluble solids of lychee honey represents the dissolved sugar content of this honey with excellent grade and considered to be highly stable upon storage [21]. Lychee honey has the potential to have high organic and amino acids which can be depicted from its acidic nature (pH-5.8) [22]. Penicillin is the earliest discovered antibiotic which belongs to the beta lactam family of antibiotic. It exhibits its mechanism of action by prohibiting the cell wall synthesis of bacteria. By inhibiting the transpeptidase enzyme, penicillin interferes the cross linking of peptidoglycan (an integral structural component of bacterial cell wall) which prevents the cell wall biosynthesis of bacteria. After losing the integrity of cell wall, bacterial cellular contents become exposed to the outside water and molecular pressure which eventually leads the bacteria to death [23]. Phenoxymethylpenicillin, a broad-spectrum beta-lactam antibiotic, exerts bactericidal effect against both Gram positive and Gramnegative bacteria that is like the mode of action of benzyl penicillin. However, the enzyme penicillinase and other beta-lactamase weakens the activity of antibiotics $[24,25]$. The beta-lactam ring of phenoxymethylpenicillin is destroyed by the bacterial enzyme betalactamase which results in its ineffectiveness by either alteration of target affinity of penicillin or decrease penetration of penicillin towards the target site that sequels in the penicillin resistance [26]

Amoxicillin, a semisynthetic penicillin, is also member of betalactam class of antibiotic which works by interfering the pathway of bacterial peptidoglycan biosynthesis by the inhibition of one or more penicillin binding proteins (PBPs). This inhibition results in the lysis of the bacterial cell wall and thus the bacteria dies [27]. However, beta-lactamase enzyme producing resistant bacteria may degrade activity of amoxicillin and therefore modifications were made in the therapeutic measure against organisms producing these enzymes [28]. Clavulanic acid is a beta-lactam, structurally resembled to penicillin, which is not as clinically effective itself to exert prospective antimicrobial response. However, clavulanic acid with amoxicillin exerts bactericidal effect against a wide range of bacteria including beta-lactamase producing bacteria [29]. So, amoxiclav resistance can be negotiated by clavulanic acid resistance. However, the hyperproduction of TEM-1 b-lactamase can also cause resistance and it is the most frequent contributor as found so far [30]. Honey is a natural sweet syrup which is considered as nutrient, preservative and considered a powerful ingredient from prophetic medicine $[31,32]$. It is a complex combination of organic acid, enzymes, trace materials and many unidentified compounds. At least 181 compounds have been identified in honey so far. Among them honey is confirmed to contain simple sugars, vitamins, proteins and free amino acids, polyphenols, carotenoids, flavonoids, calcium, potassium, phosphorus, iron, niacin, ascorbic acid and minerals [33,34]. The composition of honey largely affects its pharmacological properties however, many factors are associated with the variation in honey actual composition such as climate, honeybees and angiosperm species, how it undergoes processing etc. [35]. Presence of defensins along with its consistent amount of hydrogen peroxide and non-peroxide factors like polyphenols and flavonoids content, high sugar content, osmotic effect, low pH level etc. root honey to exert antimicrobial effect [36,37].

The dose dependent response of honey which increased along with serial dilution, can be attributed to different factors. At higher doses, the high concentration of sugar acted as preservative which resisted the microbial growth. With serial dilution though the contribution of preservative found to diminish, but the potent antimicrobial component present in honey kept resisting the growth. Alongside, due to higher concentration of the sugar, the standards might not have dispersed throughout the medium properly. But with lower concentration of honey, the standards acted side-by-side and thereby, the combinations proved to be highly effective than that of their individual application.

\section{Conclusion}

Bacterial resistance to antibiotics like penicillin and amoxiclav has become a major concern for science community. Researchers are taking many attempts and experiments to renascent those antibiotics by mean of structural modification in semi-synthetic 
manner. It is a time-consuming process with a lot of investment though. However, the efficacy of lychee honey against different bacteria, alone and in combination with antibiotic to boost its efficacy has been proved via this experiment. In the conclusion, we can say that the lychee honey has a great potential to act as a natural antimicrobial agent and resistant antibiotics can be drawn back into their action by using lychee honey along with them.

\section{Acknowledgment}

The present study was supported and carried out in the Pharmacology lab of Institute for Pharmaceutical Skill Development and Research, Bangladesh. Authors are grateful to the institute for providing such opportunity to contribute to the health science. Authors are also grateful to Centre for Medical Biotechnology (CMBT) under MIS, DGHS for providing the bacterial strains used in the study.

\section{Conflict of Interest}

All authors agreed on the article before submission and had no conflict of interests.

\section{Funding}

The research did not receive any specific grant from funding agencies in the public, commercial or not-for-profit sectors.

\section{References}

1. Frieri M, Kumar K, Boutinc A (2017) Antibiotic resistance. Journal of Infection and Public Health 10(4): 369-378.

2. Shaikh S, Fatima J, Shakil S, Mohd S, Rizvi D, Kamal MA (2015) Antibiotic resistance and extended spectrum beta-lactamases: Types, epidemiology and treatment. Saudi Journal of Biological Sciences 22(1): 90-101.

3. Ventola CL (2015) The antibiotic resistance crisis: part 1: causes and threats. Pharmacy and Therapeutics 40(4): 277-283.

4. Levy SB, Bergman MM (2003) The Antibiotic Paradox: How the Misuse of Antibiotics Destroys Their Curative Powers. Clinical Infectious Diseases 36(2): 238.

5. Bennett PM (2008) Plasmid encoded antibiotic resistance: acquisition and transfer of antibiotic resistance genes in bacteria. British Journal of Pharmacology 153(S1): S347-S357.

6. Magee JT, Pritchard EL, Fitzgerald KA, Dunstan FDJ, Howard AJ (1999) Antibiotic prescribing and antibiotic resistance in community practice: retrospective study. The BMJ 319(7219): 1239-1240.

7. Wise R, Hart T, Cars O, Streulens M, Helmuth R, et al. (1998) Antimicrobial resistance. The BMJ 317(7159): 609-610.

8. Lucera A, Costa C, Conte A, Nobile MAD (2012) Food applications of natural antimicrobial compounds. Front Microbiol 3: 287.

9. Israili ZH (2014) Antimicrobial properties of honey. American Journal of Therapeutics. 21(4): 304-323.

10. Albaridi NA (2019) Antibacterial Potency of Honey. International Journal of Microbiology p.10.

11. Ibrahim SR, Mohamed GA (2015) Litchi chinensis: medicinal uses, phytochemistry, and pharmacology. J Ethnopharmacol 174: 492-513.

12. Bhoopat L, Srichairatanakool S, Kanjanapothi D, Taesotikul T, Thananchai $\mathrm{H}$, et al. (2011) Hepatoprotective effects of lychee (Litchi chinensis Sonn.): a combination of antioxidant and anti-apoptotic activities. J Ethnopharmacol 136(1): 55-66.

13. Hwang JY, Lin JT, Liu SC, Hu CC, Shyu YS, et al. (2013) Protective role of litchi (Litchi chinensis Sonn.) flower extract against cadmium- and lead-induced cytotoxicity and transforming growth factor $\beta 1$-stimulated expression of smooth muscle $\alpha$-actin estimated with rat liver cell lines. J Funct Foods 5(2): 698-705

14. Jantakee K, Tragoolpua Y (2015) Activities of different types of Thai honey on pathogenic bacteria causing skin diseases, tyrosinase enzyme and generating free radicals. Jantakee and Tragoolpua Biological Research 48: 4.

15. Mostafa AA, Al Askar AA, Almaary KS, Dawoud TM, Sholkamy EN, et al. (2018) Antimicrobial activity of some plant extracts against bacterial strains causing food poisoning diseases. Saudi J Biol Sci 25(2): 361-366.

16. (2017) National Committee for Clinical Laboratory Standards. Methods for determining bactericidal activity of antimicrobial agents. Tentative Guidelines, M26-TNCCLS, Villanova, USA.

17. Patton T, Barett J, Brennan J, Moran N (2005) Use of a spectrophotometric bioassay for determination of microbial sensitivity to manuka honey. Microbiol Methods 64(1): 84-95.

18. Gambogou B, Khadimallah H, Bouacha M, Ameyapoh YA (2018) Antibacterial activity of various honey monofloral and polyfloral from different region of Algeria against uropathogenic Gram Negative Bacilli. J Apither 4(1): 1-8.

19. Bouacha M, Ayed H, Grara N (2018) Honey Bee as alternative medicine to treat eleven multidrug-resistant bacteria causing urinary tract infection during pregnancy. Sci Pharm 86(2): E14.

20. (2019) About Honey. Honeybee Center.

21. Vincent N, Mwanza EP, Moonga BH (2013) Physico- chemical qualities of honey harvested from different beehive types in Zambia. AJFAND 13(2).

22. Silva PM, Gauche C, Gonzaga LV, Costa ACO, Fett R Honey (2016) Chemical composition, stability and authenticity. Food Chem 196: 309-323.

23. Yocum RR, Rasmussen JR, Strominger JL (1980) The mechanism of action of penicillin. Penicillin acylates the active site of Bacillus stearothermophilus D-alanine carboxypeptidase. J Biol Chem 255(9): 3977-3986.

24. McGee L, Pletz MW, Fobiwe JP, Klugman KP (2015) Streptococcus Pneumoniae, Molecular Mechanisms of Host-Pathogen Interactions. Chapter 2: Antibiotic Resistance of Pneumococci. Academic Press p. 2140.

25. Lobanovska M, Pilla G (2017) Penicillin's Discovery and Antibiotic Resistance: Lessons for the Future. Yale J Biol Med 90(1): 135-145.

26. Venugopalan V, Klinker, KP (2019) Cell Wall Inhibitors. In Lippincott's Illustrated Reviews: Pharmacology $\left(7^{\text {th }}\right.$ edn,). Chapter 29 . Wolters Kluwer, Netherlands, pp.1047-1058

27. Akhavan BJ, Vijhani P (2019) Amoxicillin. In: Stat Pearls [Internet]. Treasure Island (FL): Stat Pearls Publishing.

28. Co EM, Schiller NL (2006) Resistance mechanisms in an in vitro-selected amoxicillin-resistant strain of Helicobacter pylori. Antimicrob Agents Chemother 50(12): 4174-4176.

29. Finlay J, Miller L, Poupard JA (2003) A review of the antimicrobial activity of clavulanate. J Antimicrob Chemother 52(1): 18-23.

30. Stapleton P, Wu PJ, King A, Shannon K, French G, et al. (1995) Incidence and Mechanisms of Resistance to the Combination of Amoxicillin and Clavulanic Acid in Escherichia coli. Antimicrob Agents Chemother 39(11): 2478-2483.

31. Mandal MD, Mandal S (2011) Honey: its medicinal property and antibacterial activity. Asian Pac J Trop. Biomed 1(2): 154-160.

32. Erejuwa 00, Sulaiman SA, Wahab MS (2012) Honey-a novel antidiabetic agent. Int J Biol Sci 8(6): 913-934.

33. Hamdy AA, Ismail HM, Al Ahwal AM, Gomaa NF (2009) Determination of flavonoid and phenolic acid contents of clover, cotton and citrus floral honeys. J Egypt Public Health Assoc 84(3-4): 245-259.

34. Burns K (2019) Health benefits of prophetic condiments: part one of five. Islam Online Arch 2000.

35. Gheldof N, Wang XH, Engeseth NJ (2012) Identification and quantification of antioxidant components of honeys from various floral sources. J Agric Food Chem 50(21): 5870-5877.

36. Alvarez Suarez JM, Giampieri F, Battino M (2013) Honey as a source of dietary antioxidants: structures, bioavailability and evidence of protective effects against human chronic diseases. Curr Med Chem 20(5): 621-638.

37. Cushnie TP, Lamb AJ (2005) Antimicrobial activity of flavonoids. Int J Antimicrob Agents 26(5): 343-356. 